\title{
Cutaneous lymphomas: A review
}

\section{Kutanöz lenfomalar: Derleme}

\author{
Denis R. Miyashiro ${ }^{1}$, ${ }^{*}$ Jose Antonio Sanches ${ }^{1}$
}

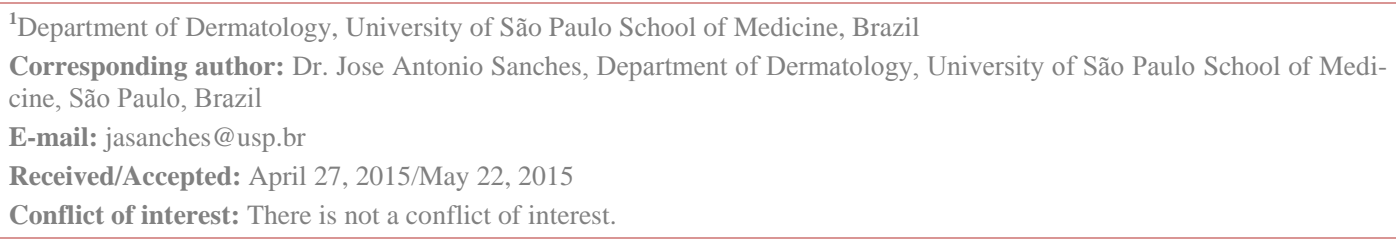

\section{SUMMARY}

Skin may be affected by non-Hodgkin lymphomas, and it is the second most frequently involved extranodal organ, after the gastrointestinal tract. Cutaneous lymphomas may originate from $\mathrm{T}, \mathrm{B}$, or NK lymphocytes. Diagnosis is difficult, and knowledge of these diseases is important to ensure their detection and adequate treatment and follow-up. Clinical picture is heterogeneous, and histology is essential to confirm the diagnosis. The classification is given by the correlation between clinical findings, histology and immunophenotyping. Therapeutic options include skin-directed therapies, immunomodulatory or low-dose immunosuppressive drugs. Rare cases of aggressive disease require systemic multidrug chemotherapy. The purpose of this review is to describe the ontogeny of T, B and NK lymphocytes, and to detail the most accepted classification of cutaneous lymphomas, proposed by the World Health Organisation and European Organisation for Research and Treatment of Cancer. Treatment of cutaneous lymphomas will be briefly discussed.

Keywords: Cutaneous lymphomas, classification, treatmen

\section{ÖZET}

Non-Hodgkin lenfomalarda cilt etkilenebilir ve gastrointestinal sistemden sonra en s1k ikinci etkilenenen ekstranodal organ deridir. Kutanöz lenfomalar T, B veya NK lenfositten köken alabilir. Tanı konulması zordur ve tanınmaları ile yeterli şekilde tedavi olup izleme alınmaları için hastalığın iyi bilinmesi gerekir. Klinik tablo heterojen olup, tanının doğrulanması için histoloji önemlidir. Sınıflandırma klinik bulgular, histoloji ve immünfenotiplemedeki korelasyon ile yapılır.Tedavi seçenekleri cilde yönelik tedaviler, immünmodülatör veya düşük doz immünsupresif tedavileri içerir. Agresif seyirli nadir vakalarda sistemik çok ilaçlı kemoterapi gerekebilir. Bu derlemenin amac1 T, B, ve NK lenfositlerinin ontogenisini tanımlamak ve Dünya Sağlık Örgütü ile Avrupa Kanser Araştırma ve Tedavi Örgütü’nün kutanöz lenfomalar için önerdiği en çok kabul gören sınıflandırmayı detaylandırmaktır. Kutanöz lenfomaların tedavisi de kısaca tartışılacaktır.

Anahtar sözcükler: Kutanöz lenfomalar, sınıflandırma, tedavi

\section{INTRODUCTION}

The skin may be affected either primarily or secondarily by lymphoproliferative processes, due to infiltration of neoplastic cells originating from other anatomical sites. Primary cutaneous lymphomas are diagnosed when there is exclusive involvement of the skin, with no evidence of lymphoproliferative disease at other sites at the time of diagnosis. If there is evidence of extracutaneous disease, the skin is considered to be secondarily involved ${ }^{1}$.
Primary cutaneous lymphomas are nonHodgkin lymphomas. The skin is the second most frequently involved extranodal organ, after the gastrointestinal tract. Cutaneous lymphomas may originate from $\mathrm{T}, \mathrm{B}$, or NK lymphocytes. The classification of cutaneous lymphomas is given by the correlation between clinical findings, histology, immunophenotyping ${ }^{2}$ ${ }^{3}$. Due to the different clinical behaviors of their systemic counterparts, the European Organisation for Research and Treatment 
of Cancer (EORTC), in 1997, and the World Health Organisation (WHO), in 2001, classified cutaneous lymphomas as separate entities of nodal lymphomas. However, there were controversies regarding cutaneous $\mathrm{T}$-cell lymphomas (CTCL) (other than mycosis fungoides (MF), Sézary syndrome (SS), and CD30+ lymphoproliferative disorders), as well as controversies regarding the classification and terminology of cutaneous B-cell lymphomas $(\mathrm{CBCL})^{4,5}$. In 2005, a consensus among members of the EORTC and
WHO was published, which provided a new classification of primary cutaneous lymphomas and other systemic diseases that often affect the skin, such as adult Tcell leukemia/lymphoma (ATLL) and CD4+CD56+ hematodermic neoplasm (blastic NK-cell lymphoma) ${ }^{1}$. This classification facilitates the distinction of indolent and aggressive forms of cutaneous lymphomas, thereby directing the treatment and follow-up of these patients (Table 1$)^{6}$.

Table 1: Classification of cutaneous lymphomas ${ }^{1}$.

\begin{tabular}{l} 
Cutaneous T-cell and NK-cell lymphomas \\
\hline Mycosis fungoides \\
MF variants and subtypes \\
\hline Folliculotropic MF \\
Pagetoid reticulosis \\
Granulomatous slack skin \\
Sézary syndrome \\
Adult T-cell leukemia/lymphoma \\
\hline \multicolumn{1}{c}{ Primary cutaneous CD30 + lymphoproliferative disorders } \\
\hline Primary cutaneous anaplastic large cell lymphoma \\
Lymphomatoid papulosis \\
Subcutaneous panniculitis-like T-cell lymphoma \\
Extranodal NK/T-cell lymphoma, nasal type \\
\hline \multicolumn{2}{c}{ Provisional entities } \\
Primary cutaneous aggressive epidermotropic CD + T-cell lymphoma \\
Cutaneous $\gamma / \partial$ T-cell lymphoma \\
Primary cutaneous CD4 + small/medium-sized pleomorphic T-cell lymphoma \\
Primary cutaneous peripheral T-cell lymphoma, unspecified \\
\hline Primary cutaneous follicle center lymphoma \\
Primary cutaneous marginal zone B-cell lymphoma \\
Primary cutaneous diffuse large B-cell lymphoma, leg type \\
Primary cutaneous diffuse large B-cell lymphoma, other \\
Intravascular large B-cell lymphoma \\
\hline$\quad$ Precursor hematologic neoplasm \\
\hline CD4+/CD56 + hematodermic neoplasm (blastic NK-cell lymphoma) \\
\hline
\end{tabular}

\section{Epidemiology}

An annual incidence rate of new cases of cutaneous lymphomas of 1 in 100,000 people is estimated to occur in the United States $^{7}$. Of primary cutaneous lymphomas, $75 \%$ are T-cell lymphomas, $25 \%$ are B-cell lymphomas, and less than $1 \%$ are NK-cell lymphomas ${ }^{7,8}$. Males are more affected than females, with a male to female ratio of 2 or 3 to 1 . The mean age at diagnosis is between 50 and 60 years of age; however, the disease may also occur in childhood ${ }^{1}$.

\section{Ontogeny of lymphocytes}

Lymphocytes originate from bone marrow stem cells. T-cells produced in the bone marrow migrate to the thymus, where they interact with the thymic stroma, leading to maturation and expression T-cell lineage markers. These lymphocytes are $\mathrm{CD} 3+\mathrm{CD} 2+\mathrm{CD} 5+\mathrm{CD} 7+$, and they can also be CD4+CD8-, CD4-CD8+, or CD4-CD8-. T-cell receptors (TCRs) may be composed by $\alpha / \beta$ or $\gamma / \delta$ heterodimers ${ }^{3}$. Initially, TCR $\alpha / \beta$ lymphocytes have double negative 
immunophenotypes for CD4 and CD8. Then, they express both markers (CD4+CD8+). Finally, differentiation occurs between the $\mathrm{CD} 4+\mathrm{CD} 8$-helper and the CD4-CD8+ cytotoxic $\mathrm{T}$ lymphocytes, where the TCR $\gamma /$ d cytotoxic lymphocytes are CD4-CD8- ${ }^{9}$. Upon leaving the thymus, these naive lymphocytes circulate into the bloodstream or migrate to peripheral lymphoid organs. When exposed to antigens originating from the skin, they express markers on their surface. This leads to a migration to the skin, as well as participation in its immune system ${ }^{10}$.

B lymphocytes are produced and undergo maturation in the bone marrow. They then migrate to secondary lymphoid organs, such as the spleen, lymph nodes, or mucosa, or stay in the bone marrow itself. When exposed to antigens, B lymphocytes can migrate to other organs ${ }^{11}$. Initially, lymph nodes are arranged in primary lymphoid follicles, which are composed of centroblasts (progenitor cells) and are not presented to antigens. Once these are presented to antigens, they turn into secondary lymphoid follicles, with a clearer central zone (the germinal center), a darker peripheral zone (the mantle zone) and a thinner zone surrounding the mantle zone (the marginal zone). Centroblasts undergo maturation and migrate from the germinal center to the mantle zone, turning into centrocytes. This maturation process occurs simultaneously with the somatic hypermutation mechanism, with an intense generation of small genetic changes in the variable component $(\mathrm{V})$ of immunoglobulins, allowing for a wide variation in its structure, facilitating the recognition of a wide range of antigen variations. After this process, B lymphocytes, with the aid of $\mathrm{T}$ helper lymphocytes, can turn into memory B-cells or plasma cells ${ }^{2}$. Thus, knowledge of the lymph node structure is important in differentiating the types of B cell lymphomas.

NK lymphocytes are produced and matured in the bone marrow. Unlike B and T lymphocytes, they are part of the body's innate immunity, without the need for prior antigen presentation; thus, they can act directly against microorganisms or tumor cells ${ }^{3}$.

\section{Diagnosis/exams}

The diagnosis of primary cutaneous lymphomas is confirmed by a histopathology analysis, with neoplastic lymphocytes infiltrating the epidermis, dermis, and/or subcutaneous tissue. However, the immunohistochemical examination is essential to complement the classification of cutaneous lymphomas. It initially differentiates among T, B, and NK cell lymphomas and then assists in classifying among these groups $^{12,13}$. The search for the clonality of the TCR gene ( $\mathrm{T}$ lymphocytes) or the heavy chains of immunoglobulins (B lymphocytes) is performed by polymerase chain reaction (PCR) or Southern blot and allows the detection of monoclonal populations, which are highly suggestive of malignant lymphoproliferative disorders. The search for clonality is a useful tool for differentiation between reactive lymphoproliferative processes (pseudolymphomas) and lymphomas ${ }^{14,}{ }^{15}$. The immunophenotyping of lymphocytes in peripheral blood is an auxiliary technique that detects malignant cells with abnormal phenotypes, as occur in Sezary syndrome (a leukemic form of cutaneous T-cell lymphoma) or in some types of adult T-cell leukemia lymphomas (ATLL) ${ }^{16-18}$. In addition to diagnostic testing, staging tests are needed, depending on the type of lymphoma and its clinical manifestations.

\section{Cutaneous T-cell lymphomas (CTCL)}

Mycosis fungoides (MF) is the most prevalent cutaneous T-cell lymphoma (CTCL), corresponding to about $50 \%$ of all cutaneous lymphomas ${ }^{8}$. It is a CD4+ effector memory T-cell neoplasm ${ }^{19}$. MF is the only primary cutaneous lymphoma with no primary lymph node malignancy counterpart. Indolent neoplasm with insidious progression can suffer a transformation to an aggressive large-cell lymphoma ${ }^{1,20}$. It is composed of different clinical variants and characterized by marked epidermotropism $^{21}$.

\section{Classical MF}

Classical MF initially presents with patches and infiltrated plaques, particularly in sun-protected areas, such as the buttocks. It can eventually progress to tumorous lesions and erythroderma ${ }^{21}$. In more advanced cases, tumorous lesions coexist 
with patches and plaques (Figure 1). If there are only tumorous lesions, then the possibility of a lymphoma other than MF must be considered ${ }^{1}$. Eventually, MF undergoes a transformation to a large-cell lymphoma, with tumorous lesions that are unresponsive to treatment and more likely to spread and involve lymph nodes ${ }^{22}$.

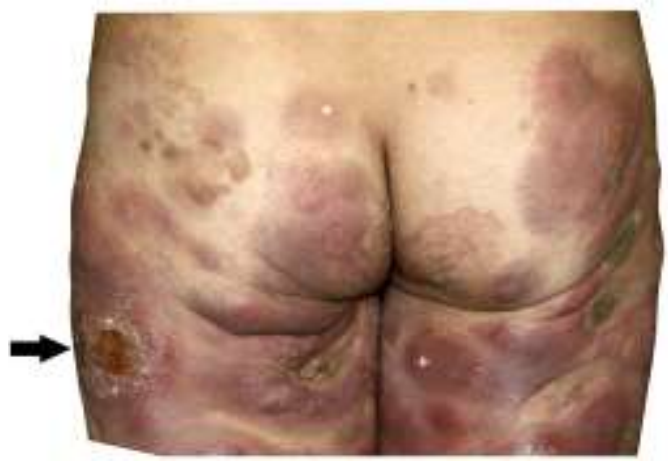

Figure 1: Classical MF. Patches (*), infiltrated plaques $(+)$ and ulcerated tumors (arrow) on the buttocks and thighs.

A typical histology shows the epidermotropism of abnormal lymphocytes, forming Pautrier microabscesses (four or more lymphocytes surrounding a Langerhans cell). The epidermis may be atrophic or hyperplastic, and there is a perivascular dermal infiltration of atypical lymphocytes.

The density of the infiltration of neoplastic lymphocytes in the skin increases from patches to plaques and tumorous lesions, but decreases in cases of erythroderma ${ }^{23}$. In cases of transformed MF, more than $25 \%$ of the cells have large and irregular cytoplasms and nuclei ${ }^{24}$. Immunohistochemistry shows a positivity for CD3 (pan$\mathrm{T}$ antigen) and CD4, as well as a variable loss of the maturation cell marker CD7 in neoplastic cells. Moreover, reactive CD8+T lymphocytes may infiltrate MF lesions. Rare cases of CD4-CD8+ or CD4+CD8+ MF have been reported, but they show no clinical or prognostic differences from the classical CD4+CD8- $\mathrm{MF}^{25}$. Genetic alterations have been described, but there is no consensus on the mutations responsible for disease susceptibility ${ }^{26}$. Staging is described in Table 2.

Table 2: Staging of $\mathrm{MF}^{17}$.

\begin{tabular}{|c|c|}
\hline \multicolumn{2}{|r|}{ TNMB stages } \\
\hline \multicolumn{2}{|r|}{ Skin } \\
\hline $\mathrm{T} 1$ & Limited patches, papules and/or plaques covering $<10 \%$ of the skin surface \\
\hline $\mathrm{T} 1$ & Patch only \\
\hline $\mathrm{T} 1$ & Patch \pm plaque \\
\hline $\mathrm{T} 2$ & Patches, papules and/or plaques covering $\geq 10 \%$ of the skin surface \\
\hline $\mathrm{T} 2$ & Patch only \\
\hline $\mathrm{T} 2$ & Patch \pm plaque \\
\hline $\mathrm{T} 3$ & One or more tumors ( $\geq 1 \mathrm{~cm}$ diameter) \\
\hline T4 & Confluence of erythema covering $\geq 80 \%$ body surface area \\
\hline \multicolumn{2}{|r|}{ Node } \\
\hline N0 & No clinically abnormal peripheral lymph nodes; biopsy not required \\
\hline N1 & Clinically abnormal peripheral lymph nodes; dermatopathic lymphadenopathy \\
\hline N1a & Clone negative \\
\hline $\mathrm{N} 1 \mathrm{~b}$ & Clone positive \\
\hline $\mathrm{N} 2$ & Clinically abnormal peripheral lymph nodes; atypical lymphocytes, preserved architecture \\
\hline $\mathrm{N} 2 \mathrm{a}$ & Clone negative \\
\hline $\mathrm{N} 2 \mathrm{~b}$ & Clone positive \\
\hline N3 & $\begin{array}{l}\text { Clinically abnormal peripheral lymph nodes; partial/complete effacement of nodal architecture by } \\
\text { atypical lymphocytes; clone positive or negative }\end{array}$ \\
\hline $\mathrm{Nx}$ & Clinically abnormal peripheral lymph nodes; no histologic confirmation \\
\hline \multicolumn{2}{|r|}{ Visceral } \\
\hline M0 & No visceral organ involvement \\
\hline M1 & Visceral involvement (must have pathology confirmation and organ involvement should be specified) \\
\hline \multicolumn{2}{|r|}{ TNMB stages } \\
\hline M1 & Visceral involvement (must have pathology confirmation and organ involvement should be specified) \\
\hline B0 & Absence of significant blood involvement: $\leq 5 \%$ of atypical peripheral blood lymphocytes \\
\hline B0a & Clone negative \\
\hline B0b & Clone positive \\
\hline & Low blood tumor burden: $>5 \%$ of atypical peripheral blood lymphocytes \\
\hline B1a & Clone negative \\
\hline $\mathrm{B} 1 \mathrm{~b}$ & Clone positive \\
\hline B2 & High blood tumor burden: $\geq 1000 / \mu \mathrm{L}$ Sézary cells or abnormal immynophenotype with positive clone \\
\hline
\end{tabular}


The five-year survival for classical MF is 93.2 to $97.3 \%$ if less than $10 \%$ of the body surface area is affected by patches and plaques (T1); 77.6 to $93.3 \%$ if more than $10 \%$ of the body surface area is affected (T2); $27.6 \%$ if tumorous lesions exist (T3); and $37.5 \%$ in erythrodermic MF (T4) ${ }^{20}$. Treatment depends on the stage and clinical presentation of the disease. For localized disease manifestations of patches and plaques, topical treatment with corticosteroids or nitrogen mustard and carmustine are effective. If the disease has been disseminated, phototherapy with UVB narrow band (UVBnb) treatment for superficial lesions or psoralen with UVA (PUVA) treatment for infiltrated plaques can be used $^{27}$. Isolated tumor lesions may be treated with excision or radiation. If multiple tumor lesions exist, a total skin electron beam is an effective option; however, this carries important side effects, such as the loss of all body hair, changes to nails, increased risk of squamous and basal cell carcinomas, burns, and a risk of cornea damage, making it necessary to use an intraocular protection ${ }^{28}$. Refractory cases with multiple tumor lesions or transformed or erythrodermic MF may require systemic treatment. Some of the systemic treatments available include: interferon $\alpha$ associated with PUVA; systemic retinoids, such as bexarotene; methotrexate; pralatrexate; monochemotherapy with chlorambucil, associated with prednisone; liposomal doxorubicin; and, in refractory cases, systemic polychemotherapy with gemcitabine and vinorelbine, and anthracycline-based schemes ${ }^{29,}{ }^{30}$. Studies with allogeneic bone marrow transplantation have shown excellent responses, with long periods of remis$\operatorname{sion}^{31}$. It is necessary to emphasize the importance of a careful indication of systemic treatment and, especially, systemic polychemotherapy because MF is an indolent neoplasm, with multiple and effective skin-directed therapies.

\section{Variants}

Folliculotropic MF predominantly affects the cephalic segment of the body with infiltrated follicular papules that converge to plaques, sometimes with acneiform aspects, keratotic plugs, cysts, and nodules, which may progress to alopecia and madarosis (Figure 2). The histology is characterized by the infiltration of the hair follicle by atypical lymphocytes with tropism, with or without associated follicular mucinosis. Inflammatory alterations, such as suppurative folliculitis, eosinophils, and even granulomatous reactions, may also be present. Since neoplastic infiltration occurs in the hair follicle, malignant cells are located deeper in the dermis. Typically, epidermotropism is mild or non-existent (in contrast with classical MF), and syringotropism may be present ${ }^{32,} 33$. The fiveyear survival of folliculotropic MF is $80 \%^{1}$. Treatment is the same as for classical MF, including skin-directed therapies, phototherapy, radiotherapy, systemic medications, and chemotherapy regimens, depending on the extent of the disease ${ }^{1,3}$.

\section{Pagetoid reticulosis}

Known as Woringer-Kolopp disease, pagetoid reticulosis is an indolent and localized variant of MF. It is usually located in the limbs and is characterized by an isolated erythematous and infiltrated plaque with psoriasiform or verrucous aspects. The histological appearance is similar to that of the classical form of MF, except for the pagetoid distribution of neoplastic cells in the epidermis. Immunohistochemistry reveals a phenotype characterized by $\mathrm{T}$ lymphocytes (CD3+) CD4+or, more often, $\mathrm{CD} 8+{ }^{35}$. There are no reports of extracutaneous dissemination or death from pagetoid reticulosis ${ }^{1}$. Radiotherapy or surgical excision may lead to long periods of remission. Other therapeutic options include topical treatment with nitrogen mustard or corticosteroid $^{1,21}$.

\section{Granulomatous slack skin}

Granulomatous slack skin is a rare variant of MF, with just over 40 cases described in the literature. It typically begins with sarcoid-infiltrated papules and plaques, usually affecting fold regions, such as the axillary and groin areas. The disease progresses with the formation of redundant skin areas and a lax aspect (Figure 3$)^{3}$. Disease progression is rare, but includes reports of granulomatous infiltrates in other organs, such as the lymph nodes and the liver. Granulomatous slack skin's histopathology 
is typical, including non-necrotizing granuloma, numerous giant cells, infiltration by atypical lymphocytes, and elastophagocytosis $^{36}$. Treatment is difficult due to the recurrence of lesions. Radiotherapy is a good option for localized disease, and surgical removal may be performed on redundant skin that causes discomfort to the patient ${ }^{37}$. Occasionally, granulomatous slack skin may be associated with classical MF or Hodgkin's lymphoma; thus, investigation is imperative to exclude such associations $^{38}$.

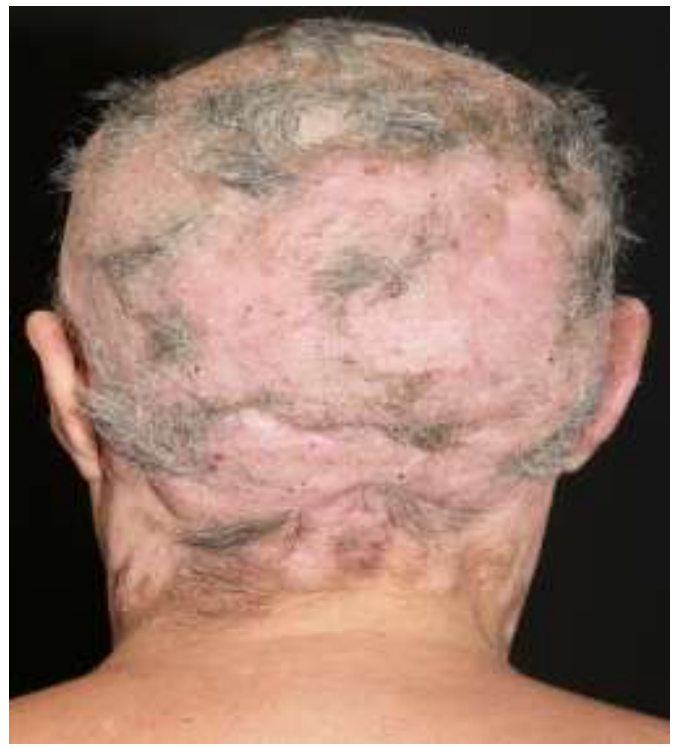

Figure 2: Follicular MF. Infiltrated plaques on the scalp and alopecia.

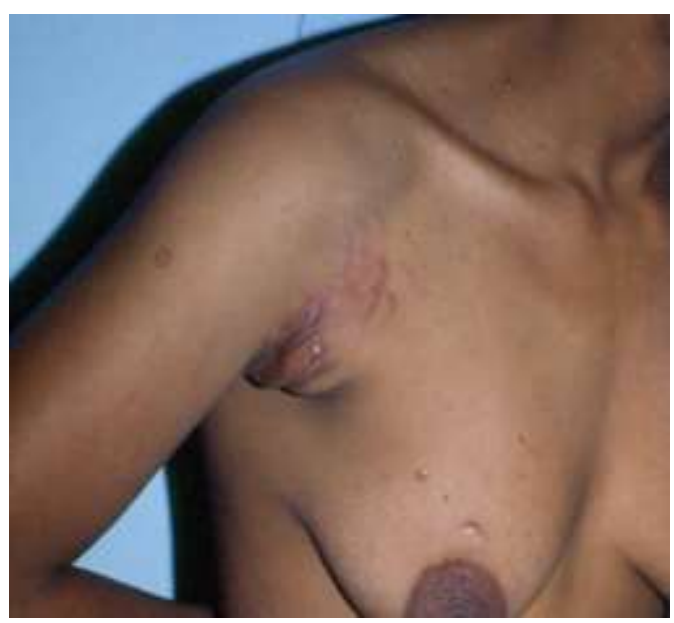

Figure 3: Granulomatous slack skin. Sarcoid-infiltrated papules and plaques on the axilla and chest, and redundant skin areas with a lax aspect on the axillary fold.

\section{Other variants}

According to the WHO-EORTC classification, other MF variants fall under the clas- sical MF umbrella, due to similar evolutions and prognoses. However, given the distinct clinical features of these variants, we will briefly review the most prevalent subtypes.

\section{Hypopigmented MF}

Hypopigmented MF commonly affects children or young adults. It is characterized by poorly defined hypochromic macules in the typical areas of classical MF, which raises the possibility of hypopigmented MF (Figure 4) ${ }^{39}$. The main differential diagnosis is pityriasis alba, which typically affects the face and the lateral parts of the arms. In hypopigmented MF lesions, the prevalence of CD8+neoplastic lymphocytes (due to their cytotoxic action) would lead to dysfunction of the melanocytes, altering melanin production and distribution and culminating in the formation of clinically hypochromic lesions ${ }^{40}$. It is an indolent disease, and treatment with topical corticosteroids, topical nitrogen mustard, or phototherapy (either UVBnb or PUVA) can induce clinical remission ${ }^{41}$.

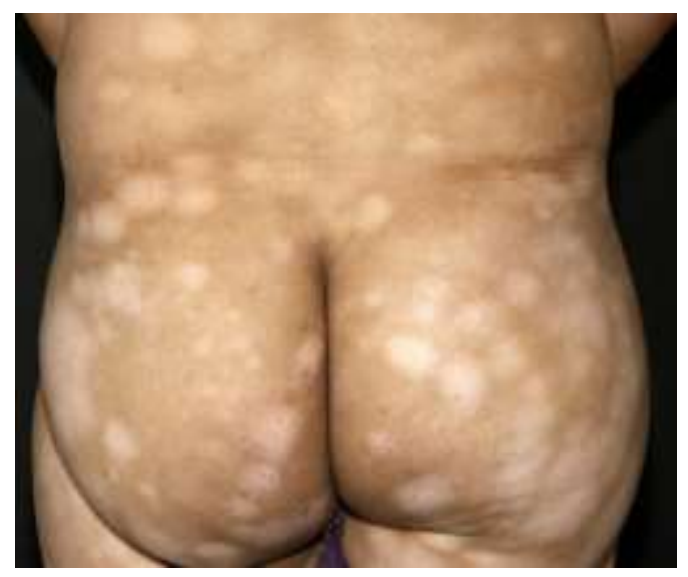

Figure 4: Hypopigmented MF. Poorly defined hypochromic macules on the buttocks.

\section{Poikilodermic MF}

Poikilodermic MF is an indolent variant characterized by hypopigmented and hyperpigmented areas, telangiectasias, and atrophy, usually in double-covered areas of the trunk and flexures ${ }^{42}$. There is a generalized form that affects almost all of the skin surface. Papular and scaly lesions, similar to those found in pityriasis lichenoides chronica, can be observed, and these may evolve into poikilodermic areas. Lymphomatoid papulosis can be associated in up to $18 \%$ of cases. The disease's histopathology includes typical MF characteristics, such as 
epidermotropism of atypical lymphocytes and epidermal atrophy, but with a more prominent hydropic degeneration of the basal layer, including pigmentary incontinence and telangiectatic vessels. Pautrier microabscesses are rarely observed. Neoplastic cells are predominantly CD $8+{ }^{42,} 43$. Treatment for poikilodermic MF is similar to that for classical MF.

\section{Other}

Other rare clinical manifestations of MF include the following variants: vesiculobullous, granulomatous, interstitial, syringotropic, MF with eruptive epidermoid cysts, palmaris et plantaris, solitary, anetodermic, invisible, ichthyosiform, papular, pustular, and verrucous ${ }^{21}$.

\section{Sézary syndrome (SS)}

SS is a leukemic form of CTCL characterized by erythroderma (i.e., erythema and scaling in more than $80 \%$ of the body surface area-Figure 5), lymphadenopathy, and peripheral blood involvement by the neoplastic cells ${ }^{1}$.

The diagnostic criteria proposed by the WHO-EORTC include a TCR gene rearrangement analysis, involving a monoclonal population of lymphocytes circulating in the peripheral blood and infiltrating the skin, as well as morphological (more than 1.000 Sézary cells per $\mathrm{mm}^{3}$ ) and/or immunophenotypic changes (CD4/CD8 $\geq 10$, CD4+CD7- $\geq 40 \% \quad \mathrm{CD} 4+\mathrm{CD} 26-\geq 30 \%$ ) in the peripheral blood (Table 3$)^{17}$. Though SS was formerly considered a leukemic form of MF, there is currently controversy regarding whether the two diseases are the same or different, since MF is an effector memory CD4+T-cell neoplasm, while SS is a central memory CD4+T-cell neoplasm. In MF, malignant lymphocytes are positive for CLA and CCR4 chemokine receptors, which confer tropism to the skin, and negative for L-selectin and CCR7 receptors, which confer tropism to lymph nodes. In contrast, in SS, there is positivity for CLA, CCR4, CCR7 and L-selectin, which would explain the frequent nodal and blood involvement ${ }^{19}$. Contrary to this theory is the emergence of typical MF lesions in patients with treated SS, particularly following the improvement of erythroderma. The existence of these lesions supports the hypothesis that MF and SS may be part of a spectral disorder ranging from exclusively cutaneous diseases to those with skin, nodal, and hematological involvement.

Other clinical findings in patients with SS include: non-scarring diffuse alopecia, palmoplantar keratoderma and fissures, onychodystrophy, and variable degrees of skin infiltration. Patients may complain of intense pruritus, weight loss, fevers, and chills. These clinical findings are nonspecific, and they are also found in varying frequencies in erythrodermic patients with different etiologies, highlighting the importance of extensive laboratory research seeking to determine the cutaneous and blood involvement of neoplastic cells in erythrodermic patients ${ }^{44-46}$.

Table 3. Sézary syndrome criteria ${ }^{48}$.

Positive clonal rearrangement of TCR by PCR or southern blot plus one of the following

Sézary cell count $\geq 1000 / \mu \mathrm{L}$

CD4/CD8 ratio $\geq 10$

CD4+CD7- $\geq 40 \%$

CD4+CD26- $\geq 30 \%$

The prognosis of SS is poor, with a median survival of four years after diagnosis (or $42.3 \%$ at five years) ${ }^{45}$. The main prognostic factors include age at diagnosis and tumor burden, as measured by LDH levels, the $\mathrm{CD} 4 / \mathrm{CD} 8$ ratio, and the absolute Sézary cell count ${ }^{47}$.

The first choice of treatment is extracorporeal photopheresis, wherein, by means of apheresis, the blood lymphocytes are separated, exposed to a photosensitizer (psoralen), irradiated with UVA, and reinfused into the patient. Other treatment options include phototherapy with PUVA or UVBnb; total skin electron beam radiation; interferon $\alpha$ or $\gamma$; bexarotene; denileukin diftitox; methotrexate; histone deacetylase inhibitors (vorinostat and romidepsin); alemtuzumab (anti-CD52 monoclonal antibody); chlorambucil combined with prednisone; systemic chemotherapy with gemcitabine and vinorelbine; and anthracycline-based schemes. As in MF, multidrug polychemotherapy for SS has partial and transient responses, with rapid relapses and minimal impact on overall survival $^{48}$. Allogeneic bone marrow transplantation reports show promising results concerning the sustained remission of the disease $^{49}$. 
Adult $\mathrm{T}$ cell leukemia/lymphoma (ATLL) is a disease associated with HTLV-1, a retrovirus endemic in some parts of the world, such as Japan, Central-Western Brazil, the Caribbean, and sub-Saharan Africa. The evolution to ATLL occurs in 1 to $5 \%$ of infected patients, after years (or even decades) of infection ${ }^{1}$. Considered a systemic neoplasm, ATLL manifests in cutaneous ways in about $50 \%$ of patients ${ }^{85}$.

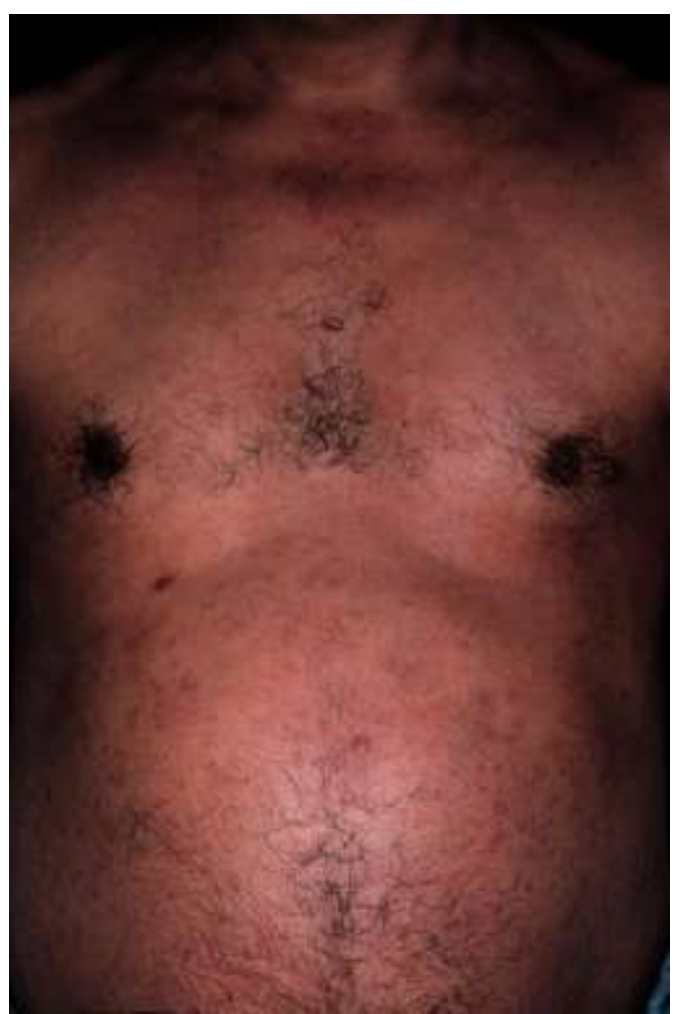

Figure 5: Sézary syndrome. Erythroderma (diffuse erythema and scaling affecting more than $80 \%$ of the body surface area).

Shimoyama's classification is the most used classification method for ATLL. This system divides cases into four subtypes: acute, lymphomatous, chronic, and smoldering $^{86}$. The acute and lymphomatous types have worse prognoses, median survivals of 6.2 and 10.2 months, respectively; the chronic and smoldering types, on the other hand, have better prognoses, with median survivals of 24.3 and 154 months, respectively ${ }^{85,87}$. However, patients with the lymphomatous, chronic, and smoldering types may experience acute crises, which involve high mortality ${ }^{85}$. The clinical manifestations of ATLL are varied, including papules, plaques, nodules, tumors, ichthyosiform aspects, purpura, and even erythroderma, and the type of skin lesion has an impact on the prognosis. The nodulo-tumoral and erythrodermic forms have significantly worse prognoses, with median survivals of 17.3 and 3 months, respectively ${ }^{88}$.

A definitive diagnosis of ATLL is given by identifying the integration of proviral DNA into the neoplastic cell genome ${ }^{18}$. Histologically, the disease is characterized by the infiltration of the dermis by diffuse medium to large neoplastic cells, sometimes with marked epidermotropism (which is difficult to distinguish from MF). The immunophenotype of the malignant lymphocytes is characterized by positivity for CD3, CD4, and CD25 (interleukin-2 receptor) ${ }^{89}$. Treatment is based on clinical signs, with skin-directed therapy or interferon associated with zidovudine in indolent cases and with systemic multidrug therapy or bone marrow transplantation in aggressive cases ${ }^{1,18}$. Phase 2 clinical trials with the anti-CCR4 monoclonal antibody mogamulizulab are currently being conducted, and these show promising responses thus far in refractory and aggressive cases ATLL $^{90}$.

\section{Primary cutaneous CD30+ lymphopro- liferative disorders}

Primary cutaneous CD30+ lymphoproliferative disorders are a group of indolent cutaneous lymphomas characterized by the expression of CD30 on the cell surface. They comprise a spectrum of diseases classified between cutaneous anaplastic large T-cell lymphoma (C-ALCL) and lymphomatoid papulosis (LyP). The lesions may undergo autoregression and rarely progress to extracutaneous disease.

\section{Cutaneous anaplastic large T-cell lym- phoma (C-ALCL)}

Cutaneous anaplastic large T-cell lymphoma (C-ALCL) is characterized by isolated or grouped papules, nodules, or tumors, which may ulcerate and undergo autoregression. Unlike nodal anaplastic large T-cell lymphoma (ALCL), C-ALCL has a good prognosis, with a five-year survival of $95 \%{ }^{1}$. The disease's histology shows the dermal infiltration of diffuse cells with large and irregular nuclei, prominent nucleoli, and abundant cytoplasm. The neoplastic lymphocytes are CD4 +, 
expressing CD30 in over $75 \%$ of cells. Moreover, unlike its nodal counterpart, CALCL is usually negative for anaplastic lymphoma kinase (ALK), which is present in nodal anaplastic lymphomas with t (2; 5) $(\mathrm{p} 23 ; \mathrm{q} 35)^{50,51}$. Excision and radiotherapy are the most common treatments for localized disease. In the case of multifocal lesions, low-dose methotrexate is effective. In rapidly progressive cases or extracutaneous diseases, systemic polychemotherapy regimens including doxorubicin may be used $^{52-54}$. Currently, a phase 2 study using brentuximab (anti CD30 monoclonal antibody approved for the treatment of Hodgkin's lymphoma) is being conducted in CALCL cases ${ }^{55}$.

\section{Lymphomatoid papulosis (LyP)}

Lymphomatoid papulosis (LyP) is an indolent neoplasm of CD4+ T lymphocytes, with grouped papules that progress to central necrosis and spontaneous involution, usually involving the trunk and limbs (Figure 6). Commonly, lesions in different stages of evolution can be found. The disease may be associated with MF, C-ALCL, and Hodgkin's lymphoma ${ }^{50,52}$. LyP manifests in four histologic types: Type A involves large and sometimes multinucleated cells, similar to the Reed-Sternberg cells of Hodgkin's lymphoma, which infiltrate the dermis and are surrounded by inflammatory cells. Type B involves the epidermotropism of small lymphocytes with cerebriform nuclei; thus, it simulates the characteristics of MF, but with a lower expression of CD30. Type $\mathrm{C}$ is similar to $\mathrm{C}$ ALCL, with dermal infiltration of large lymphocytes and few inflammatory cells. Finally, type D involves the epidermotropic infiltration of small/medium-sized CD8+ CD30+lymphocytes, similar to the case of primary cutaneous aggressive epidermotropic CD8 + cytotoxic T-cell lymphoma $^{54,56,57}$. Diagnoses are made by clinical and pathological correlation, since the disease's histology may be identical to that of MF or C-ALCL. Topical corticosteroids, phototherapy, or low dose methotrexate (in the case of multiple lesions) are the treatments performed; the "wait and see" strategy is also valid ${ }^{54}$. The prognosis of LyP is excellent, with $100 \%$ survival at five-year follow-up ${ }^{1}$.
Subcutaneous panniculitis-like T-cell lymphoma Subcutaneous panniculitis-like Tcell lymphoma is an indolent CTCL with a cytotoxic atypical lymphocyte infiltration of the subcutaneous tissue. Initially, the disease involves plaques and nodules, which progress to form sclerotic and atrophic areas with retractable aspects, mainly in the lower limbs. These lesions are often indistinguishable from the lesions of inflammatory panniculitis. Hemophagocytic syndrome is a severe associated complication, indicating a worse prognosis ${ }^{1,58}$. Histologically, pleomorphic malignant cells arranged around adipocytes in lobbular patterns can be observed, as in cases of lobular panniculitis (e.g., lupus panniculitis). Immunohistochemistry reveals $\mathrm{CD} 3+$ T-cells, CD4 -, CD8 +, $\beta \mathrm{F} 1+(\mathrm{TCR} \alpha / \beta$ marker), TIA+, granzyme $\mathrm{B}+$, and perforin $+{ }^{59-61}$. Progression to a more aggressive disease or extracutaneous dissemination is rare, and the five-year survival is $82 \%^{1}$. There is no standard treatment; however, there are reports of good responses to radiotherapy, systemic corticosteroids, cyclosporine, and multidrug chemotherapy in doxorubicin-based regimens ${ }^{62,63}$.

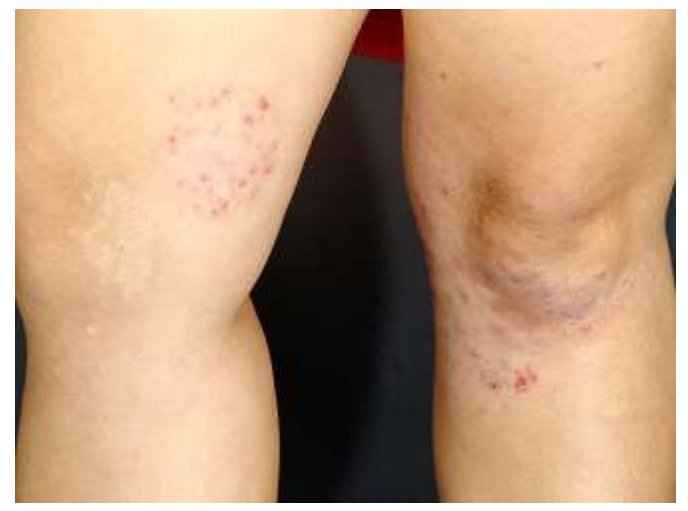

Figure 6: Lymphomatoid papulosis. Grouped papules with central necrosis on the legs. Lesions in different stages of evolution can be seen.

Extranodal NK/T-cell lymphoma, nasal type Previously known as lethal midline granuloma, due to its tendency to affect the nasal and nasopharyngeal regions, this rare lymphoma has an aggressive course and is often associated with EBV infection. It presents as papules and infiltrated nodules on the face, which quickly ulcerate, leading to tissue destruction. Systemic symptoms, such as fevers and chills, may be 
present, as may hemophagocytic syndrome $^{64,65}$. The disease's histology shows a dense infiltration of neoplastic cells in the dermis and subcutaneous tissue, including angiocentrism and intense inflammatory infiltrates composed by lymphocytes, histiocytes, and eosinophils. Patients with nasal-type extranodal NK/T-cell lymphoma, may exhibit an $\mathrm{NK}(75 \%)$ or T-cell phenotype $(25 \%)^{65-68}$. The prognosis is poor, with a median survival of less than 12 months $^{64,}$ 69. Lactate dehydrogenase levels and B symptoms are associated with poorer prognoses ${ }^{70}$. Early and aggressive treatment particularly, radiotherapy associated with systemic polychemotherapy should be instituted ${ }^{64,69}$.

\section{Provisional entities}

In the WHO-EORTC classification, some types of cutaneous lymphomas do not fit into any of the well-established subtypes; thus, provisional entities were created.

\section{Primary cutaneous aggressive epider- motropic CD8 + cytotoxic T-cell lym- phoma}

This is a rare and aggressive type of lymphoma that must be distinguished from other cutaneous lymphomas with CD8 expression, such as pagetoid reticulosis and rare cases of MF, C-ALCL, and $\mathrm{LyP}^{71}$. Clinically, it presents with disseminated erythematous and violaceous infiltrated papules and nodules, as well as central necrosis ${ }^{1,72}$. The disease rapidly disseminates to extracutaneous sites; however, nodal involvement is $\operatorname{rare}^{73}$. There is marked epidermotropism of malignant lymphocytes, as well as nodular or diffuse dermal infiltration that may extend to the subcutaneous tissue. Immunohistochemistry shows the existence of CD3 + CD4CD8+ malignant lymphocytes with high cell proliferation indexes (Ki-67). The prognosis of this variant of lymphoma is poor, with a median survival of 22 to 32 months. Treatment involves doxorubicinbased systemic chemotherapy, total skin electron beam, bexarotene and bone marrow transplantation ${ }^{72}$.

\section{Cutaneous $\gamma / \delta$ T-cell lymphoma}

The T-cell receptor (TCR) heterodimer is formed by a combination of $\alpha / \beta$ or $\gamma / \delta$ chains. Most cutaneous lymphomas are composed of lymphocytes with a TCR $\alpha / \beta$ chain ${ }^{15}$. Cytotoxic $\gamma / \delta$ T lymphocytes share the characteristics of the innate and adaptive immune systems, and they are present in large quantities in the $\operatorname{skin}^{74}$. However, the lymphomas originating from these cells are very rare. Dermatologically, they are characterized by ulcerated and necrotic nodules, preferably in the limbs. The disease is extremely aggressive: It escalates rapidly to extracutaneous disease and can be associated with hemophagocytic syndrome $^{75-77}$. Medium to large neoplastic cells infiltrate the epidermis, dermis, and/or subcutaneous tissue, with marked angiodestruction and necrosis. Immunohistochemistry shows positivity for $\mathrm{CD} 3$, $\mathrm{CD} 2$ and CD56, along with a CD4- and CD8- phenotype. Since $\beta F 1$, a TCR $\alpha / \beta$ marker, is negative, it can be concluded that these cells are TCR $\gamma / \delta^{78}$. Given the median survival of 15 months, treatment via systemic multidrug chemotherapy must be instituted as soon as possible; however, the results are often disappointing ${ }^{1,79}$.

Primary cutaneous CD4+ small/mediumsized pleomorphic T-cell lymphoma (SMPTCL) is an indolent T-cell lymphoma characterized by the infiltration of CD4+ pleomorphic T-cells, but lacking the epidermotropism evident in MF. It presents as a solitary infiltrated plaque or tumor in the face, neck, or upper trunk. Histologically, there is a proeminent nodular or diffuse dermal infiltration of atypical cells, with mild and focal epidermotropism ${ }^{1,80}$. Neoplastic cells are small- to medium-sized pleomorphic lymphocytes. Its prognosis is good: The disease tends to be limited to the skin, and the five-year survival is $75 \%{ }^{1}$. Often, distinguishing between primary cutaneous CD4+ small/medium-sized pleomorphic T-cell lymphoma and Tpseudolymphomas is difficult, even with TCR gene rearrangement analysis, which may be polyclonal in up to $40 \%$ of SMPTCL patients. For this reason, Beltraminelli et al. suggested the name "cutaneous nodular proliferation of pleomorphic $\mathrm{T}$ lymphocytes of undetermined significance" for these cases ${ }^{81}$. In cases of a single lesion, treatment with surgical excision or radiotherapy may be performed. There is no consensus regarding the treatment of 
disseminated lesions; however, there are reports of good responses to treatment with interferon $\alpha$ or cyclophosphamide ${ }^{3,}{ }^{82}$. Spontaneous regression has also been described $^{81}$.

\section{Primary cutaneous peripheral T-cell lymphoma, unspecified}

This heterogeneous cutaneous lymphoma group cannot be classified into any of the well-established subtypes or provisional entities. Usually involving single or multiple nodules and tumors, the disease may progress rapidly to the lymph nodes and visceral involvement. The histology, in most cases, shows a nodular or diffuse infiltration of medium to large-sized pleomorphic CD3+CD4+CD8- lymphocytes; however, cases with CD3+CD4-CD8+, CD3+CD4-CD8-, and CD3+CD4+CD8+ phenotypes have also been described. The disease prognosis is poor, with a five-year survival of less than $20 \%$. Treatment with systemic multidrug therapy is imperative ${ }^{80,}$ 83,84 .

\section{Precursor hematologic neoplasm/CD4+ CD56+ hematodermic neoplasm}

Formerly known as blastic NK-cell lymphoma, this is an extremely rare neoplasm of blastic plasmacytoid dendritic cells ${ }^{91}$. It is considered a systemic disease with secondary cutaneous involvement, which presents as erythematous and violaceous infiltrated plaques and nodules. Though it most often begins in the trunk region, it progresses rapidly to the lymph nodes, bone marrow, peripheral blood, and other visceral areas. The disease histology shows a diffuse and dense infiltration of medium neoplastic cells in the dermis and subcutaneous tissue, with numerous mitotic figures and few inflammatory cells. Its malignant cells are $\mathrm{CD} 3+\mathrm{CD} 4+\mathrm{CD} 56+$ $\mathrm{CD} 123+{ }^{92,93}$.

The prognosis is poor, with a median survival of 14 months, and treatment is accomplished through systemic multidrug therapy and bone marrow transplant ${ }^{64,94,95}$.

\section{Cutaneous B-cell lymphomas (CBCL)/Primary cutaneous follicle cen- ter lymphoma}

This is the most common subtype of CBCL, accounting for approximately 55\% of CBCLs, and it is characterized by a proliferation of centrocytes and centroblasts from the germinal centers of the normal secondary lymphoid follicles ${ }^{1,96}$. It manifests as single or multiple nodules or tumors on the face and upper trunk (Figure 7). A subtype with tumors surrounded by erythematous and infiltrated plaques in the back, was formerly known as Crosti lymphoma $^{97}$. It is an indolent disease, and systemic involvement is rare; however, the disease may transform into diffuse large Bcell lymphoma, with a more aggressive course. Histologically, atypical centrocytes and centroblasts, which act as diffuse or nodular infiltrates in the dermis and simulate a germinal center, have been observed. Immunohistochemistry reveals negativity for CD3 (pan-T antigen) and positivity for CD20, CD19, CD79a, and bc16. CD10 is positive in cases of follicular patterns and negative in cases of diffuse patterns. Bcl2 is either negative or expressed by few neoplastic cells, and it is associated with a higher probability of extracutaneous involvement ${ }^{96,98}$. The disease prognosis is very good, with a five-year survival of $95 \%{ }^{1}$. Local treatments with radiation therapy, excision, and intralesional corticosteroids are effective. For patients with multiple lesions or extracutaneous dissemination, anthracycline-based chemotherapy or systemic or intralesional anti-CD20 monoclonal antibodies (rituximab) can be used $^{1,99,100}$. If a transformation to highgrade lymphoma occurs, systemic multidrug therapy is necessary ${ }^{101}$.

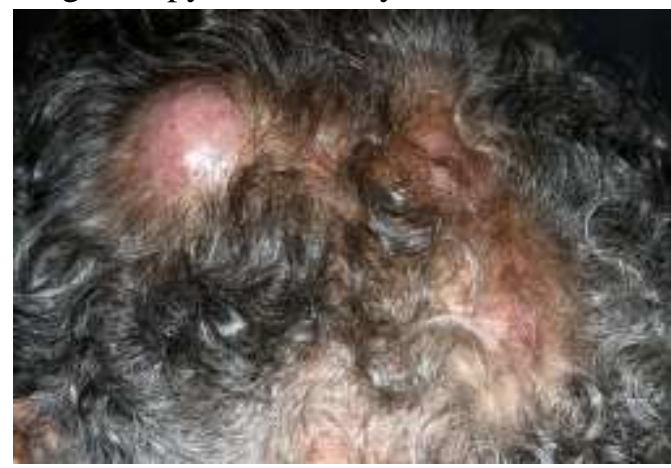

Figure 7: Follicle center B-cell lymphoma. Multiple nodules on the scalp.

Primary cutaneous marginal-zone B-cell lymphoma

This variant is a neoplasm with centrocytelike cells, simulating the marginal zone of secondary lymphoid follicles ${ }^{2}$. There are reports of an association with the Borrelia 
burgdorferi infection in Europe ${ }^{102}$. Clinically, the disease is characterized by erythematous and violaceous papules and nodules, located primarily on the trunk and upper limbs. Similar to follicle center lymphoma, primary cutaneous marginal-zone B-cell lymphoma may progress to more aggressive forms, such as diffuse large Bcell lymphoma ${ }^{1}$. Its histology shows nodular and/or diffuse infiltrates in the dermis, with a darker center composed of small lymphocytes. This center is surrounded by a clearer area of medium cells with abundant cytoplasm, similar to centrocytes. There may be inflammatory cells in the interfollicular areas, thereby making the differentiation of marginal-zone B-cell lymphoma and pseudolymphomas more challenging ${ }^{103}$. The neoplastic cells are CD20+CD19+CD10-CD79a+, bcl2+, and bcl6-; however, the reactional germinal centers are bcl6+, CD10+, and bcl2- ${ }^{2,101 \text {, }}$ ${ }^{104}$. The disease prognosis is very good, with a five-year survival of $100 \%{ }^{1}$. Treatment for single or grouped lesions can be accomplished with radiotherapy or surgical excisions. For cases associated with infection by Borrelia burgdorferi, systemic antibiotics should be introduced $^{102}$. If the disease is multifocal or extracutaneous, interferon $\alpha$, chlorambucil or intralesional or systemic anti-CD20 monoclonal antibody (rituximab) can be used $^{104-106}$.

\section{Primary cutaneous diffuse large B-cell lymphoma, leg type}

This is an intermediate form of CBCL, which characteristically affects the lower limbs. It manifests as nodules and tumors of rapid growth in the legs, which may rapidly disseminate to the lymph nodes ${ }^{107}$, 108 . Reports of primary cutaneous diffuse large B-cell lymphoma affecting other topographies are rare. Its histology shows centroblasts and immunoblasts in a diffuse infiltrate pattern, which affect the dermis and subcutaneous tissue. Moreover, a presence of mitotic figures and a rarity of reactive $\mathrm{T}$ lymphocytes have been observed ${ }^{1,2}$. Immunohistochemistry shows positivity for CD20, CD19, CD79a, bcl2, and bcl6 and negativity for $\mathrm{CD} 10^{101,109}$. The fiveyear survival is $55 \%$, with a worse prognosis in the case of multiple lesions ${ }^{1,}{ }^{108}$. Treatment is done with an anti-CD20 monoclonal antibody (rituximab), applied either alone or in combination with radiotherapy and other chemotherapeutic drugs. Response rates are good, but relapses occur frequently ${ }^{99,106,110 .}$

\section{Primary cutaneous diffuse large B-cell lymphoma, other}

This is an intermediate form of CBCL, which includes rare cases of large B-cell lymphomas that do not belong to either primary cutaneous diffuse large B-cell lymphoma (leg type) or follicle center lymphoma. Generally, this group includes plasmablastic and anaplastic variants of diffuse large B-cell lymphomas, B-cell lymphomas rich in inflammatory $\mathrm{T}$-cells and histiocytes, and cutaneous manifestations of systemic lymphomas. Clinically, variants in this group resemble follicle center and marginal zone B-cell lymphomas, with nodules and tumors affecting the head, trunk, and extremities. The disease's five-year survival is $50 \% \%^{1,2,111}$.

\section{Intravascular large B-cell lymphoma}

This is a rare variant of CBCL with an intermediate prognosis. Clinically, it manifests as papules, infiltrated plaques, and telangiectasias, located predominantly on the trunk and lower limbs. The disease usually affects the central nervous system, lungs and $\operatorname{skin}^{112}$. Histologically, large and atypical lymphocytes in the blood vessels of the dermis and subcutaneous tissue are observed; the neoplastic cells are positive for CD20, CD79a, bcl2, and bcl6, but often negative for $\mathrm{CD} 10^{113}$. The three-year survival is 22 to $56 \%$, depending on the presence or absence of extracutaneous disease $^{114}$. Early treatment with systemic polychemotherapy is imperative.

In conclusion; this skin is the second-mostaffected extranodal site with regard to nonHodgkin lymphomas (preceded only by the gastro-intestinal tract). Unlike nodal lymphomas, most cutaneous lymphomas are derived from T-lymphocytes; moreover, MF is the most prevalent cutaneous lymphoma. It has numerous variants, each with a different clinical manifestation and prognosis. The diagnosis of cutaneous lymphomas is difficult; thus, knowledge of these entities is important to ensure their detection, in order to perform an early diagnosis. 
We highlight the need for careful evaluation prior to the use of systemic polychemotherapy in primary cutaneous lymphomas, since most of these diseases are indolent, with numerous therapeutic options, such as skin-directed therapies and immunomodulatory or low-dose immunosuppressive drugs. Systemic multidrug therapy is reserved for rare cases of aggressive disease, with rapid progression to extracutaneous involvement or refractory cases of extensive skin lesions. In addition to the deleterious side effects of polychemotherapy, patients of systemic multidrug therapy suffer partial and transient responses, with high rates of relapse and disease progression. It is also important to note that patients should be treated by a dermatologist, hematologist, oncologist, and radiation oncologist collaboratively, since a holistic approach is critical to better managing the treatment and follow-up of these patients.

\section{REFERENCES}

1. Willemze R, Jaffe ES, Burg G, Cerroni L, Berti E, Swerdlow SH, Ralfkiaer E, Chimenti S, DiazPerez JL, Duncan LM, Grange F, Harris NL, Kempf W, Kerl H, Kurrer M, Knobler R, Pimpinelli N, Sander C, Santucci M, Sterry $\mathrm{W}$, Vermeer $\mathrm{MH}$, Wechsler J, Whittaker S, Meijer CJ. WHOEORTC Blood 2005; 105: 376885.

2. De Moricz CZM, Sanches Jr JA. Lymphoproliferative processes of the skin. Part 1-Primary cutaneous B-cell lymphomas. An Bras Dermatol 2005; 80: 461-71.

3. Sanches Jr JA, de Moricz CZM, Neto CF. Lymphoproliferative processes of the skin. Part 2Cutaneous T-cell and NK-cell lymphomas. An Bras Dermatol 2006; 81: 7-25.

4. Willemze R, Kerl H, Sterry W, Berti E, Cerroni L, Chimenti S, Diaz-Peréz JL, Geerts ML, Goos M, Knobler R, Ralfkiaer E, Santucci M, Smith N, Wechsler J, van Vloten WA, Meijer CJ. EORTC classification for primary cutaneous lymphomas: A proposal from the Cutaneous Lymphoma Study
Group of the European Organization for Research and Treatment of Cancer. Blood 1997; 90: 354-71.

5. Jaffe ES, Harris NL, Stein H, Vardiman JW (Eds). World Health Organization classification of tumors: Pathology and genetics of tumours of hematopoietic and lymphoid tissues. Ann Oncol 2002; 13: 490-1.

6. Slater DN. The new World Health Organization-European Organization for Research and Treatment of Cancer classification for cutaneous lymphomas: a practical marriage of two giants. Br J Dermatol 2005; 153: 874-80.

7. Groves FD, Linet MS, Travis LB, Devesa SS. Cancer surveillance series: non-Hodgkin's lymphoma incidence by histologic subtype in the United States from 1978 through 1995. J Natl Cancer Inst 2000; 92: 1240-51.

8. Bradford PT, Devesa SS, Anderson WF, Toro JR. Cutaneous lymphoma incidence patterns in the United States: a population-based study of 3884 cases. Blood 2009; 113: 5064-73.

9. Rothemberg EV. T-lineage specification and commitment: A gene regulation perspective. Semin Immunol 2002; 14: 431-40.

10. Kupper TS, Fuhlbrigge RC. Immune surveillance in the skin: mechanisms and clinical consequences. Nat Rev Immunol 2004; 4: 211-22.

11. Ichii M. Early B lymphocyte development: Similarities and differences in human and mouse. World J Stem Cells 2014; 6: 421-31.

12. Smoller BR, Santucci M, Wood GS, Whittaker SJ. Histopathology and genetics of cutaneous T-cell lymphoma. Hematol Oncol Clin North Am 2003; 17: 1277-311.

13. Fung MA, Murphy MJ, Hoss DM, Grant-Kels JM. Practical evaluation and management of cutaneous lymphoma. J Am Acad Dermatol 2002; 46: 325-60.

14. Ponti R, Quaglino P, Novelli M, Fierro MT, Comessatti A, Peroni 
A, Bonello L, Bernengo MG. Tcell receptor $\gamma$ gene rearrangement by multiplex polymerase chain reaction/heteroduplex analysis in patients with cutaneous T-cell lymphoma (mycosis fungoides/Sézary syndrome) and benign inflammatory disease: Correlation with clinical, histological and immunophenotypical findings. Br J Dermatol 2005; 153: 565-73.

15. Chitgopeker P, Sahni D. T-cell receptor gene rearrangement detection in suspected cases of cutaneous $\mathrm{T}$-cell lymphoma. $\mathrm{J}$ Invest Dermatol 2014; 134: 19.

16. Nagler AR, Samimi S, Schaffer A, Vittorio CC, Kim EJ, Rook AH. Peripheral blood findings in erythrodermic patients: Importance for the differential diagnosis of Sézary syndrome. J Am Acad Dermatol 2012; 66: 503-8.

17. Olsen E, Vonderheid E, Pimpinelli N, Willemze R, Kim Y, Knobler R, Zackheim H, Duvic M, Estrach T, Lamberg S, Wood G, Dummer R, Ranki A, Burg G, Heald P, Pittelkow M, Bernengo MG, Sterry W, Laroche L, Trautinger F, Whittaker S. Revisions to the staging and classification of mycosis fungoides and Sézary syndrome: A proposal of the International Society for Cutaneous Lymphomas (ISCL) and the cutaneous lymphoma task force of the European Organization of Research and Treatment of Cancer (EORTC). Blood 2007; 110: 1713-22.

18. Verdonck K, González E, Van Dooren S, Vandamme A-M, Vanham G, Gotuzzo E. Human Tlymphotropic virus 1: Recent knowledge about an ancient infection. Lancet Infect Dis 2007; 7: 266-81.

19. Campbell JJ, Clark RA, Watanabe R, Kupper TS. Sézary syndrome and mycosis fungoides arise from distinct T-cell subsets: A biologic rationale for their distinct clinical behaviors. Blood 2010; 116: 76771.

20. Desai M, Liu S, Parker S. Clinical characteristics, prognostic factors, and survival of 393 patients with mycosis fungoides and Sézary syndrome in the southeastern United States: A single-institution cohort. J Am Acad Dermatol 2015; 72: 276-85.

21. Ahn CS, ALSayyah A, Sangüeza OP. Mycosis fungoides: An updated review of clinicopathologic variants. Am J Dermatopathol 2014; 36: 933-48.

22. Benner MF, Jansen PM, Vermeer $\mathrm{MH}$, Willemze R. Prognostic factors in transformed mycosis fungoides: a retrospective analysis of 100 cases. Blood 2012; 119: 16439.

23. Guitart J, Kennedy J, Ronan S, Chmiel JS, Hsiegh Y-C, Variakojis D. Histologic criteria for the diagnosis of mycosis fungoides: Proposal for a grading system to standardize pathology reporting. J Cutan Pathol 2001; 28: 174-83.

24. Salhany KE, Cousar JB, Greer JP, Casey TT, Fields JP, Collins RD. Transformation of cutaneous $\mathrm{T}$ cell lymphoma to large cell lymphoma. A clinicopathologic and immunologic study. Am J Pathol 1988; 132: 265-77.

25. Dewar R, Andea AA, Guitart J, Arber DA, Weiss LM. Best practices in diagnostic immunohistochemistry: workup of cutaneous lymphoid lesions in the diagnosis of primary cutaneous lymphoma. Arch Pathol Lab Med 2015; 139: 338-50.

26. Zhang Y, Wang Y, Yu R, Huang Y, Su M, Xiao C, Martinka M, Dutz JP, Zhang X, Zheng Z, Zhou Y. Molecular markers of earlystage mycosis fungoides. J Invest Dermatol 2012; 132: 1698-706.

27. Ponte P, Serrão V, Apetato M. Efficacy of narrowband UVB vs. PUVA in patients with early-stage mycosis fungoides: nbUVB vs. PUVA in early-stage MF. J Eur Acad Dermatol Venereol 2009; 24: 716-21.

28. Harrison C, Young J, Navi D, Riaz N, Lingala B, Kim Y, Hoppe R. 
Revisiting low-dose total skin electron beam therapy in mycosis fungoides. Int J Radiat Oncol Biol Phys 2011; 81: 651-7.

29. Wu PA, Huang V, Bigby ME. Interventions for mycosis fungoides: Critical commentary on a Cochrane Systematic Review. Br J Dermatol 2014; 170: 1015-20.

30. Jawed SI, Myskowski PL, Horwitz S, Moskowitz A, Querfeld C. Primary cutaneous T-cell lymphoma (mycosis fungoides and Sézary syndrome). J Am Acad Dermatol 2014; 70: 205-16.

31. Schlaak M, Theurich S, Pickenhain J, Skoetz N, Kurschat P, von Bergwelt-Baildon M. Allogeneic stem cell transplantation for advanced primary cutaneous T-cell lymphoma: A systematic review. Crit Rev Oncol Hematol 2013; 85: 21-31.

32. Demirkesen C, Esirgen G, Engin B, Songur A, Oğuz O. The clinical features and histopathologic patterns of folliculotropic mycosis fungoides in a series of 38 cases: Clinical features of FMF. J Cutan Pathol 2015; 42: 22-31.

33. Marschalkó M, Erős N, Kontár O, Hidvégi B, Telek J, Hársing J, Jókai H, Bottlik G, Rajnai $H$, Szepesi A, Matolcsy A, Kárpáti S, Csomor J. Folliculotropic mycosis fungoides: clinicopathological analysis of 17 patients. J Eur Acad Dermatol Venereol 2014; 18.

34. Van Doorn R, Scheffer E, Willemze R. Follicular mycosis fungoides: A distinct disease entity with or without associated follicular mucinosis. Arch Dermatol 2001; 138: 191-8.

35. Haghighi B, Smoller BR, LeBoit PE, Warnke RA, Sander CA, Kohler S. Pagetoid reticulosis: An immunophenotypic, molecular, and clinicopathologic study. Mod Pathol 2000; 13: 502-10.

36. Tsuruta D, Kono $\mathrm{T}$, Kutsuna $\mathrm{H}$, Yashiro N, Ishii M. Granulomatous slack skin: An ultrastructural study. J Cutan Pathol 2001; 28: 44-8.
37. Clarijs M, Poot F, Laka A, Pirard C, Bourlond A. Granulomatous slack skin: Reatment with extensive surgery and review of the literature. Dermatology 2003; 206: 393-7.

38. van Haselen CW, Toonstra J, van der Putte SJ, van Dongen JJ, van Hees CL, van Vloten WA. Granulomatous slack skin: Report of three patients with an updated review of the literature. Dermatology 1998; 196: 382-91.

39. Castano E, Glick S, Wolgast L, Naeem R, Sunkara J, Elston D, Jacobson M. Hypopigmented mycosis fungoides in childhood and adolescence: A long-term retrospective study: Hypopigmented MF in childhood. J Cutan Pathol 2013; 40: 924-34.

40. Furlan FC, de Paula Pereira BA, da Silva LF, Sanches JA. Loss of melanocytes in hypopigmented mycosis fungoides: A study of 18 patients: Loss of melanocytes in MF. J Cutan Pathol 2014; 41: 1017.

41. Furlan FC, Sanches JA. Hypopigmented mycosis fungoides: A review of its clinical features and pathophysiology. An Bras Dermatol 2013; 88: 954-60.

42. Abbott RA, Sahni D, Robson A, Agar N, Whittaker S, Scarisbrick JJ. Poikilodermatous mycosis fungoides: A study of its clinicopathological, immunophenotypic, and prognostic features. J Am Acad Dermatol 2011; 65: 313-9.

43. Shiomi T, Monobe Y, Kuwabara C, Hayashi H, Yamamoto T, Sadahira Y. J Cutan Pathol 2013; 40: 317-20.

44. Vonderheid EC. On the diagnosis of erythrodermic cutaneous T-cell lymphoma. J Cutan Pathol 2006; 33: 27-42.

45. Kubica AW, Davis MD, Weaver AL, Killian JM, Pittelkow MR. Sézary syndrome: A study of 176 patients at Mayo Clinic. J Am Acad Dermatol 2012; 67: 1189-99.

46. Pal S, Haroon TS. Erythroderma: A clinico-etiologic study of 90 
cases. Int J Dermatol 1998; 37: 104-7.

47. Vidulich KA, Talpur R, Bassett RL, Duvic M. Overall survival in erythrodermic cutaneous T-cell lymphoma: An analysis of prognostic factors in a cohort of patients with erythrodermic cutaneous T-cell lymphoma. Int J Dermatol 2009; 48: 243-52.

48. Olsen EA, Rook AH, Zic J, Kim Y, Porcu P, Querfeld C, Wood G, Demierre MF, Pittelkow M, Wilson LD, Pinter-Brown L, Advani R, Parker S, Kim EJ, JunkinsHopkins JM, Foss F, Cacchio P, Duvic M. Sézary syndrome: Immunopathogenesis, literature review of therapeutic options, and recommendations for therapy by the United States Cutaneous Lymphoma Consortium (USCLC). J Am Acad Dermatol 2011; 64: 352404.

49. Wu PA, Kim YH, Lavori PW, Hoppe RT, Stockerl-Goldstein KE. A meta-analysis of patients receiving allogeneic or autologous hematopoietic stem cell transplant in mycosis fungoides and sézary syndrome. Biol Blood Marrow Transplant 2009; 15: 982-90.

50. Liu HL, Hoppe RT, Kohler S, Harvell JD, Reddy S, Kim YH. Cd30+cutaneous lymphoproliferative disorders: The stanford experience in lymphomatoid papulosis and primary cutaneous anaplastic large cell lymphoma. J Am Acad Dermatol 2003; 49: 1049-58.

51. DeCouteau JF, Butmarc JR, Kinney MC, Kadin ME. The $t(2 ; 5)$ chromosomal translocation is not a common feature of primary cutaneous CD30 lymphoproliferative disorders: comparison with anaplastic large cell lymphoma of nodal origin. Blood 1996; 87: 3437-41.

52. Bekkenk MW, Geelen FA, van Voorst VPC, Heule F, Geerts ML, van Vloten WA, Meijer CJ, Willemze R. A report from the Dutch Cutaneous Lymphoma Group on the long-term follow-up data of
219 patients. Blood 2000; 95: 3653-61.

53. Vonderheid EC, Sajjadian A, Kadin ME. Methotrexate is effective therapy for lymphomatoid papulosis and other primary cutaneous CD30-positive lymphoproliferative disorders. J Am Acad Dermatol 1996; 34: 470-480.

54. Kempf W, Pfaltz K, Vermeer MH, Cozzio A, Ortiz-Romero PL, Bagot M, Olsen E, Kim YH, Dummer R, Pimpinelli N, Whittaker S, Hodak E, Cerroni L, Berti E, Horwitz S, Prince HM, Guitart J, Estrach T, Sanches JA, Duvic M, Ranki A, Dreno B, OstheerenMichaelis S, Knobler R, Wood G, Willemze R. EORTC, ISCL, and USCLC consensus recommendations for the treatment of primary cutaneous CD30-positive lymphoproliferative disorders: lymphomatoid papulosis and primary cutaneous anaplastic large-cell lymphoma. Blood 2011; 118: 4024-35.

55. Duvic M, Reddy SA, Pinter-Brown L, Korman NJ, Zic J, Kennedy DA, Lorenz J, Sievers EL, Kim YH. A phase II study of SGN-30 in cutaneous anaplastic large cell lymphoma and related lymphoproliferative disorders. Clin Cancer Res 2009; 15: 6217-24.

56. El Shabrawi-Caelen L, Kerl H, Cerroni L. Lymphomatoid papulosis: Reappraisal of clinicopathologic presentation and classification into subtypes $\mathrm{A}, \mathrm{B}$, and $\mathrm{C}$. Arch Dermatol 2004; 140: 441-7.

57. Kadin M, Nasu K, Sako D, Said J, Vonderheid E. Lymphomatoid papulosis. A cutaneous proliferation of activated helper T cells expressing Hodgkin's diseaseassociated antigens. Am J Pathol 1985; 119: 315-25.

58. Marzano AV, Berti E, Paulli M, Caputo R. Cytophagocytic histiocytic panniculitis and subcutaneous panniculitis-like T-cell lymphoma. Arch Dermatol 2000; 136: 889-96.

59. Hoque SR, Child FJ, Whittaker SJ, 
Ferreira S, Orchard G, Jenner K, Spittle M, Russell-Jones R. Subcutaneous panniculitis-like T-cell lymphoma: A clinicopathological, immunophenotypic and molecular analysis of six patients. Br J Dermatol 2003; 148: 516-25.

60. Takeshita M, Imayama S, Oshiro $\mathrm{Y}$, Kurihara K, Okamoto S, Matsuki Y, Nakashima Y, Okamura T, Shiratsuchi M, Hayashi T, Kikuchi M. Clinicopathologic analysis of 22 cases of subcutaneous panniculitis-like CD56- or CD56+lymphoma and review of 44 other reported cases. Am J Clin Pathol 2004; 121: 408-16.

61. Bosisio F, Boi S, Caputo V, Chiarelli C, Oliver F, Ricci R, Cerroni L. Lobular panniculitic infiltrates With overlapping histopathologic features of lupus panniculitis (lupus profundus) and subcutaneous T-cell lymphoma: a conceptual and practical dilemma. Am J Surg Pathol 2015; 39: 206-11.

62. Lee WS, Hwang JH, Kim MJ, Go SI, Lee A, Song HN, Lee MJ, Kang MH, Kim HG, Lee JH. Cyclosporine $\mathrm{A}$ as a primary treatment for panniculitis-like $\mathrm{T}$ cell lymphoma: a case with a longterm remission. Cancer Res Treat 2014; 46: 312-6.

63. Guenova E, Schanz S, Hoetzenecker W, DeSimone JA, Mehra T, Voykov B, UrosevicMaiwald M, Berneburg M, Dummer R, French LE, Kerl K, Kamarashev J. Fierlbeck G, Cozzio A. Systemic corticosteroids for subcutaneous panniculitis-like T-cell lymphoma. Br J Dermatol. 2014; 171: 891-4.

64. Bekkenk MW. CD56+hematological neoplasms presenting in the skin: A retrospective analysis of 23 new cases and 130 cases from the literature. Ann Oncol 2004; 15: 1097-108.

65. Jaffe ES, Krenacs L, Raffeld M. Classification of cytotoxic T-cell and natural killer cell lymphomas. Semin Hematol 2003; 40: 175-84.

66. Chan JK, Sin VC, Wong KF, Ng
CS, Tsang WY, Chan $\mathrm{CH}$, Cheung MM, Lau WH. Nonnasal lymphoma expressing the natural killer cell marker CD56: A clinicopathologic study of 49 cases of an uncommon aggressive neoplasm. Blood 1997; 89: 4501-13.

67. Natkunam Y, Smoller BR, Zehnder JL, Dorfman RF, Warnke RA. Aggressive cutaneous NK and NK-like T-cell lymphomas: clinicopathologic, immunohistochemical, and molecular analyses of 12 cases. Am J Surg Pathol 1999; 23: 571-81.

68. Jhuang JY, Chang ST, Weng SF, Pan ST, Chu PY, Hsieh PP, Wei $\mathrm{CH}$, Chou SC, Koo CL, Chen CJ, Hsu JD, Chuang SS. Extranodal natural killer/T-cell lymphoma, nasal type in Taiwan: a relatively higher frequency of T-cell lineage and poor survival for extranasal tumors. Hum Pathol 2015; 46: 313-21.

69. Cheung MM, Chan JK, Lau WH, Foo W, Chan PT, Ng CS, Ngan RK. Primary non-Hodgkin's lymphoma of the nose and nasopharynx: Clinical features, tumor immunophenotype, and treatment outcome in 113 patients. J Clin Oncol 1998; 16: 70-7.

70. Takata K, Hong M, Sitthinamsuwan $\mathrm{P}$, Loong $\mathrm{F}$, Tan SY, Liau JY, Hsieh PP, Ng SB, Yang SF, Pongpruttipan T, Sukpanichnant S, Kwong YL, Hyeh Ko Y, Cho YT, Chng WJ, Matsushita T, Yoshino T, Chuang SS. Primary cutaneous NK/T-cell lymphoma, nasal type and CD56positive peripheral T-cell lymphoma: A cellular lineage and clinicopathologic study of 60 patients from Asia. Am J Surg Pathol 2015; 39: 1-12.

71. Lu D, Patel KA, Duvic M, Jones D. Clinical and pathological spectrum of CD8-positive cutaneous Tcell lymphomas. J Cutan Pathol 2002; 29: 465-72.

72. Nofal A, Abdel-Mawla MY, Assaf M, Salah E. Primary cutaneous aggressive epidermotropic 
CD8+T-cell lymphoma: Proposed diagnostic criteria and therapeutic evaluation. J Am Acad Dermatol 2012; 67: 748-59.

73. Berti E, Tomasini D, Vermeer MH, Meijer CJ, Alessi E, Willemze R. Primary cutaneous CD8positive epidermotropic cytotoxic $\mathrm{T}$ cell lymphomas: A distinct clinicopathological entity with an aggressive clinical behavior. Am J Pathol 1999; 155: 483-92.

74. Nakamizo S, Egawa G, Tomura M, Sakai S, Tsuchiya S, Kitoh A, Honda T, Otsuka A, Nakajima S, Dainichi T, Tanizaki H, Mitsuyama M, Sugimoto Y, Kawai K, Yoshikai Y, Miyachi Y, Kabashima K. Dermal V $\gamma 4(+) \gamma \delta$ T cells possess a migratory potency to the draining lymph nodes and modulate CD8 (+) T-cell activity through TNF- $\alpha$ production. J Invest Dermatol 2015; 135: 1007-15.

75. Berti E, Cerri A, Cavicchini S, Delia D, Soligo D, Alessi E, Caputo R. Primary cutaneous gamma/delta lymphoma presenting as disseminated pagetoid reticulosis. J Invest Dermatol 1991; 96: 718-23.

76. Harrington L, Sokol L, Holdener S, Shao H, Zhang L. Cutaneous gamma-delta T-cell lymphoma with central nervous system involvement: report of a rarity with review of literature: Cutaneous $\gamma \delta$ T-cell lymphoma involving CNS. J Cutan Pathol 2014; 41: 936-43.

77. Alexander RE, Webb AR, AbuelHaija M, Czader M. Rapid progression of primary cutaneous gamma-delta T-cell lymphoma with an initial indolent clinical presentation. Am J Dermatopathol 2014; 36: 839-42.

78. de Wolf-Peeters C, Achten R. Gamma-delta T-cell lymphomas: a homogeneous entity? Histopathology 2000; 36: 294-305.

79. Toro JR. Gamma-delta T-cell phenotype is associated with significantly decreased survival in cutaneous T-cell lymphoma. Blood 2003; 101: 3407-12.

80. Bekkenk MW. Peripheral T-cell lymphomas unspecified presenting in the skin: Analysis of prognostic factors in a group of 82 patients. Blood 2003; 102: 2213-9.

81. Beltraminelli H, Leinweber B, Kerl H, Cerroni L. Primary cutaneous CD4+small-/medium-sized pleomorphic T-cell lymphoma: A cutaneous nodular proliferation of pleomorphic T lymphocytes of undetermined significance? A study of 136 cases. Am J Dermatopathol 2009; 31: 317-22.

82. Friedmann D, Wechsler J, Delfau MH, Estève E, Farcet JP, de Muret A, Parneix-Sparke A, Vaillant L, Revuz J, Bagot M. Primary cutaneous pleomorphic small T-cell lymphoma. Arch Dermatol 1995; 131: 1009-15.

83. Beljaards RC, Meijer CJ, van der Putte SC, Hollema H, Geerts ML, Bezemer PD, Willemze R. Primary cutaneous T-cell lymphomas: clinicopathologic features and prognostic parameters of 35 cases other than mycosis fungoides and CD30-positive large cell lymphoma. J Pathol 1994; 172: 53-60.

84. Grange F, Hedelin G, Joly P, Beylot-Barry M, D'Incan M, Delaunay M, Vaillant L, Avril MF, Bosq J, Wechsler J, Dalac S, Grosieux C, Franck N, Esteve E, Michel C, Bodemer C, Vergier B, Laroche L, Bagot M. Prognostic factors in primary cutaneous lymphomas other than mycosis fungoides and the Sézary syndrome. Blood 1999; 93: 3637-42.

85. Tokura Y, Sawada Y, Shimauchi T. Skin manifestations of adult Tcell leukemia/lymphoma: Clinical, cytological and immunological features. J Dermatol 2014; 41: 1925.

86. Shimoyama M. Diagnosis criteria and classification of clinical subtypes of adult T-cell leukemialymphoma: A report from the Lymphoma Study Group. Br J Haematol 1991; 79: 428-37.

87. Yamada Y, Tomonaga M, Fukuda $\mathrm{H}$, Hanada S, Utsunomiya A, Tara M, Sano M, Ikeda S, Takatsuki K, 
Kozuru M, Araki K, Kawano F, Niimi M, Tobinai $K$, Hotta $T$, Shimoyama M. A new G-CSFsupported combination chemotherapy, LSG15, for adult T-cell leukaemia-lymphoma: Japan Clinical Oncology Group Study 9303. Br J Haematol 2001; 113: 375-82.

88. Sawada Y, Hino R, Hama K, Ohmori S, Fueki H, Yamada S, Fukamachi S, Tajiri M, Kubo R, Yoshioka M, Nakashima D, Sugita K, Yoshiki R, Shimauchi T, Mori T, Izu K, Kobayashi M, Nakamura M, Tokura Y. Type of skin eruption is an independent prognostic indicator for adult T-cell leukemia/lymphoma. Blood 2011; 117: 3961-7.

89. Ohshima K, Suzumiya J, Sato K, Kanda M, Sugihara M, Haraoka S, Takeshita M, Kikuchi M. Nodal Tcell lymphoma in an HTLV-I endemic area: Proviral HTLV-I DNA, histological classification and clinical evaluation. $\mathrm{Br} \mathrm{J}$ Haematol 1998; 101: 703-11.

90. Ishida T, Jo T, Takemoto S, Suzushima H, Uozumi K, Yamamoto K, Uike N, Saburi Y, Nosaka K, Utsunomiya A, Tobinai K, Fujiwara H, Ishitsuka K, Yoshida S, Taira $\mathrm{N}$, Moriuchi $\mathrm{Y}$, Imada K, Miyamoto $\mathrm{T}$, Akinaga $\mathrm{S}$, Tomonaga $\mathrm{M}$, Ueda R. Dose-intensified chemotherapy alone or in combination with mogamulizumab in newly diagnosed aggressive adult T-cell leukaemia-lymphoma: A randomized phase II study. Br J Haematol 2015 in press.

91. Jacob MC, Chaperot C, Mossuz P, Feuillard J, Valensi F, Leroux D, Béné $\mathrm{MC}$, Bensa JC, Brière $\mathrm{F}$, Plumas J. CD4 CD56 lineage negative malignancies: A new entity developed from malignant early plasmacytoid dendritic cells. Haematologica 2003; 88: 941-55.

92. Wang W, Li W, Jia JJ, Zheng Y, Wang $\mathrm{H}$, Gao XM, Dong XY, Tian Q, Jing HL, Wang X, Xiao SX. Blastic plasmacytoid dendritic cell neoplasm: A case report. Oncol Lett 2015; 9: 1388-92.
93. Park SH, Chi HS, Cho YU, Jang S, Park CJ. Leukemic manifestation of blastic plasmacytoid dendritic cell neoplasm: laboratory approaches in 2 cases. Blood Res 2014; 49: 198-200.

94. Petrella T, Comeau MR, Maynadié M, Couillault G, De Muret A, Maliszewski CR, Dalac S, Durlach A, Galibert L. Agranular CD4+CD56+hematodermic neoplasm'(blastic NK-cell lymphoma) originates from a population of CD56+precursor cells related to plasmacytoid monocytes. Am J Surg Pathol 2002; 26: 852-62.

95. Riaz W, Zhang L, Horna P, Sokol L. Blastic plasmacytoid dendritic cell neoplasm: update on molecular biology, diagnosis, and therapy. Cancer Control 2014; 21: 279-89.

96. Pham-Ledard A, Cowppli-Bony A, Doussau A, Prochazkova-Carlotti M, Laharanne E, Jouary T, Belaud-Rotureau MA, Vergier B, Merlio JP, Beylot-Barry M. Diagnostic and prognostic value of BCL2 rearrangement in 53 patients with follicular lymphoma presenting as primary skin lesions. Am $\mathbf{J}$ Clin Pathol 2015; 143: 362-73.

97. Crosti A. Micosi fungoide e reticuloistiocitomi cutanei maligni. Minerva Dermat 1951; 26: 3-11.

98. De Leval L, Harris NL, Longtine J, Ferry JA, Duncan LM. Cutaneous B-cell lymphomas of follicular and marginal zone types: use of Bcl-6, CD10, Bcl-2, and CD21 in differential diagnosis and classification. A J Surg Pathol 2001; 25: 732-41.

99. Heinzerling LM, Urbanek M, Funk JO, Peker S, Bleck O, Neuber K, Burg G, von Den Driesch P, Dummer R. Reduction of tumor burden and stabilization of disease by systemic therapy with antiCD20 antibody (rituximab) in patients with primary cutaneous Bcell lymphoma. Cancer 2000; 89: 1835-44.

100. Paul T, Radny P, Kröber SM, Paul A, Blaheta H-J, Garbe C. Intralesional rituximab for cutaneous B-cell lymphoma. Br J Derma- 
tol 2001; 144: 1239-43.

101. Wilcox RA. Cutaneous Bcell lymphomas: 2015 update on diagnosis, risk-stratification, and management. Am J Hematol 2015; 90: 73-6.

102. Cerroni L, Zöchling N, Pütz B, Kerl H. Infection by Borrelia burgdorferi and cutaneous Bcell lymphoma. J Cutan Pathol 1997; 24: 457-61.

103. Goyal A, Moore JB, Gimbel D, Carter JB, Kroshinsky D, Ferry JA, Harris NL, Duncan LM. PD-1, S-100 and CD1a expression in pseudolymphomatous folliculitis, primary cutaneous marginal zone B-cell lymphoma (MALT lymphoma) and cutaneous lymphoid hyperplasia: PD-1 and CD1a in lymphoma and pseudolymphoma. J Cutan Pathol 2015; 42: 6-15.

104. Zenahlik P, Fink-Puches R, Kapp KS, Kerl H, Cerroni L. Die Therapie der primären kutanen B-Zell-Lymphome. Der Hautarzt 2000; 51: 19-24.

105. Soda R, Constanzo A, Cantonetti M, Orlandi A, Bianchi L, Chimenti S. Systemic therapy of primary cutaneous B-cell lymphoma, marginal zone type, with rituximab, a chimeric anti-CD20 monoclonal antibody. Acta Derm Venereol 2001; 81: 207-8.

106. Kim MJ, Hong ME, Maeng $\mathrm{CH}$, Jung HA, Hong JY, Choi MK, Kim SJ, Ko YH, Kim WS. Clinical features and treatment outcomes of primary cutaneous B-cell lymphoma: a singlecenter analysis in South Korea. Int J Hematol 2015; 101: 273-8.

107. Vermeer MH, Geelen FAMJ, van Haselen CW, van Voorst Vader PC, Geerts ML, val Vloten WA, Willemze R. Primary cutaneous large B-cell lymphomas of the legs: A distinct type of cutaneous B-cell lymphoma with an intermediate prognosis. Arch Dermatol 1996; 132: 1304-8.

108. Grange F, Bekkenk MW, Wechsler J, Meijer C, Cerroni L, Bernengo M, Bosq J, Hedelin G,
Fink Puches R, van Vloten WA, Joly P, Bagot M, Willemze R. Prognostic factors in primary cutaneous large B-cell lymphomas: a European multicenter study. J Clin Oncol 2001; 19: 3602-10.

109. Hoefnagel JJ, Vermeer MH, Janssen PM, Fleuren GJ, Meijer CJLM, Willemze R. Bcl-2, Bcl-6 and CD10 expression in cutaneous B-cell lymphoma. $\mathrm{Br} \mathrm{J}$ Dermatol 2003; 149: 1183-91.

110. Brogan BL, Zic JA, Kinney MC, Hu JY, Hamilton KS, Greer JP. Large B-cell lymphoma of the leg: Clinical and pathologic characteristics in a north american series. J Am Acad Dermatol 2003; 49: $223-8$.

111. Suárez AL, Pulitzer $\mathrm{M}$, Horwitz S, Moskowitz A, Querfeld C, Myskowski PL. Primary cutaneous B-cell lymphomas: Part I. Clinical features, diagnosis, and classification. J Am Acad Dermatol 2013; 69: 1-13.

112. Perniciaro C, Winkelmann RK, Daoud MS, Su WPD. Malignant angioendotheliomatosis is anangiotropic intravascular lymphoma: Immunohistochemical, ultrastructural and molecular genetic studies. Am J Dermatopathol 1995; 17: 242-8.

113. Nguyen GH, Yassin AH, Magro CM. Unusual variants of intravascular malignant hematopoietic neoplasms: A report of 4 cases and review of the literature. Am J Dermatopathol 2015 in press.

114. Ferreri AJM, Campo E, Seymour JF, Willemze R, Ilariucci F, Ambrosetti A, Zucca E, Rossi G, López-Guillermo A, Pavlovsky MA, Geerts ML, Candoni A, Lestani M, Asioli S, Milani M, Piris MA, Pileri S, Facchetti F, Cavalli F, Ponzoni M. Intravascular lymphoma: clinical presentation, natural history, management and prognostic factors in a series of 38 cases, with special emphasis on the "cutaneous variant". $\mathrm{Br} \mathrm{J}$ Haematol 2004; 127: 173-83. 